\title{
Tradução Literária: 0 que tentamos traduzir?
}

\author{
Literary Translation: what are we trying to translate?
}

\section{Marco David Castro da Silva}

\begin{abstract}
Resumo: A concepção da tradução como campo individualizado dentro dos estudos das linguagens é bastante recente e cada vez mais se atentam para as dificuldades intrínsecas ao processo pouco percebidas pelo leitor comum. Em se tratando da tradução literária, as peculiaridades que surgem são de tal forma acentuadas, que levaram pensadores a questionar através dos anos se a tradução de textos literários seria sequer possível. Considerando um referencial teórico acerca da literatura como expressão de subjetividade e a mensagem inserida no texto literário, este trabalho visa discutir em que medida a literatura, de fato, pode ser traduzida ou o que significa traduzir a literatura. Ao final do artigo concluímos que o texto literário em toda sua pluralidade, enquanto comunicação e enquanto arte, precisa ser visto como sendo composto de diferentes dimensões que surgem pelo diálogo entre a subjetividade do autor e do leitor. Em cada texto algumas dessas dimensões são mais facilmente traduzidas que outras e, em alguns casos, de fato parecem ser intraduzíveis, onde entraria exatamente a tarefa criativa do tradutor.
\end{abstract}

Palavras-chave: Tradução Literária, Estudos da Tradução, traduzibilidade, tradução criativa.

Abstract: The conception of translation as an individualized field within the studies of languages is quite recent and more and more attention is being paid to the intrinsic difficulties in the process little perceived by the common reader. When it comes to literary translation, the peculiarities that emerge are so accentuated that they have led thinkers to question over the years whether the translation of literary texts would even be possible. Considering a theoretical framework about literature as an expression of subjectivity and the message inserted in the literary text, this work aims to discuss the extent to which literature, in fact, can be translated or what it means to translate literature. At the end of the article, we conclude that the literary text in all its plurality, as communication and as art, needs to be seen as being composed of different dimensions that arise through the dialogue between the subjectivity of the author and the reader. In each text, some of these dimensions are more easily translated than others, and in some cases, in fact, they seem to be untranslatable, and that's where the translator's creative task would enter.

Keywords: Literary translation, translation studies, translatability, creative translation. 


\section{Introdução}

A atividade tradutória vem por milênios sendo fundamental em sua tarefa de permitir a interação entre diferentes povos e culturas, rompendo as barreiras impostas pelos idiomas. Apesar disso, era sempre tratada como um ramo secundário de outras disciplinas, como a linguística. Mas no atual mundo globalizado, com cargas de informação em exponencial crescimento, a tradução passou a ser vista como imprescindível e veio a ganhar cada vez mais importância. Talvez por isso apenas muito recentemente passou a ser vista como disciplina própria, mas pode-se dizer que nasceu, dentro da cultura humana, concomitantemente à própria comunicação. Isso porque o que se entende como tradução atualmente vai além da visão usual do senso comum, onde surge como $o$ ato de verter um texto de uma língua para outra.

De fato, as línguas são apenas uma pequena parte do tema, pois a tradução, na verdade, diz respeito a qualquer transposição de informação de uma linguagem para outra. Ou seja, antes de ser material para a atuação da atividade tradutória, a própria formação de um idioma já traz em si um processo de tradução, pois é uma das formas que o ser humano encontrou para materializar sua dimensão pessoal mental, vontades, sensações ou necessidades numa forma de expressão compreensível para o outro, seja com sons e ruídos na fala ou símbolos gráficos na escrita. Então, teríamos a formação de um idioma quando um grupo de pessoas se põe "mais ou menos de acordo em que esses grupos de ruídos ou signos devem corresponder a determinado objeto, ação ou condição" (POUND, 2006, p. 32). Se há comunicação, há tradução, mesmo que dentro de um mesmo idioma. Roman Jakobson (2007) identificou três formas básicas de tradução, sendo elas a intralingual ou reformulação, que acontece dentro de um mesmo idioma; a interlingual ou tradução propriamente dita, e a intersemiótica, que ocorre entre linguagens diferentes, como uma transposição de um livro para o cinema, por exemplo.
A tradução, seja qual modelo for, apresenta dificuldades e especificidades que a torna uma atividade bem distante de um viés mecânico ou puramente técnico. Este artigo tem como foco a modalidade interlingual, entre diferentes línguas, onde um determinado conteúdo apresentado num idioma fonte deve ser transposto para um idioma alvo. Ainda dentro desta, nosso objeto específico seria a tradução de textos literários cujos aspectos tão próprios e peculiares nos leva a entender esta prática como uma disciplina própria dentro dos estudos da tradução.

\section{O que estamos tentando traduzir?}

Com o surgimento da linguagem escrita, o ser humano teve em mãos um dos meios mais refinados e eficientes de transmitir uma mensagem, de expressar ideias, ações ou sensações. A partir daí, a literatura passou a ser parte da identidade humana.

Ezra Pound, poeta e tradutor americano, dá uma concisa, mas bastante acertada, definição do que seria literatura ao chamá-la linguagem escrita carregada de significado (POUND, 2006, p. 32). Claro, a partir desta única frase temos numerosas questões a serem examinadas. Ainda assim, o que há de mais importante nesta afirmação fica à mostra desde o primeiro instante: há algo a ser imbuído na linguagem escrita que pode torná-la diferenciada. Quando somado a esse algo, a palavra torna-se literatura, torna-se arte. Aliás, Pound ainda afirma que esta qualidade da literatura comportaria gradações, o que faria com que determinada obra pudesse ser várias vezes visitada pelo receptor sem que isso logo levasse ao seu esgotamento. Em contrapartida, outras seriam facilmente deixadas de lado após poucas fruições.

Considerando esta premissa, chegamos pelo menos a outras duas conclusões significativas. A primeira é que deve existir a mesma linguagem escrita não acrescida deste diferencial. De fato, podemos ter num manual técnico, por exemplo, a palavra escrita, dotada de sentido e perfazendo comunicação com toda clareza. Mas esta, sem o significado carregado, não poderia dizer-se literatura. Portanto, o segundo ponto, mais relevante, é que este algo a mais não se encontra 
exatamente na fisicalidade do texto, mas emerge do conjunto da obra e, especialmente, do contato do leitor com ela.

Umberto Eco traz uma reflexão semelhante ao estabelecer que na arte - por conseguinte, também na literatura - as obras seriam abertas, ou seja, passíveis "de mil interpretações diferentes, sem que isso redunde em alteração em sua irreproduzível singularidade. Cada fruição é, assim, uma interpretação e uma execução" (ECO, 2005, p. 40), e a obra se refaz a cada nova visitação de um leitor. Em contrapartida, uma obra ou texto fechado possui seu significado limitado a si mesmo, como no dito manual técnico ou, talvez, uma placa de trânsito. Claro, ainda existe a necessidade de um receptor para decodificar aquela mensagem e completar o processo de comunicação, mas o papel deste receptor, em um texto fechado, seria apenas de receber aquela mensagem e compreender sua dimensão factual e de registro. Já nas obras abertas, o receptor tem a tarefa de executar uma atividade de interpretação de um contexto implícito, como será discutido mais à frente. É como se na obra literária - e na arte como um todo - a linguagem exigisse a aplicação do que Paul Grice (1975) denominou princípio de cooperação, ou seja, é preciso que obra e leitor entrem num trabalho conjunto para que os significados carregados no texto possam emergir. Grice discute os aspectos da comunicação direta, da conversação, e aponta que neste processo ambas as partes precisam contribuir de forma complementar para que este se efetue. Pode-se dizer que a literatura exige uma conversação assíncrona entre escritor e leitor.

Quando Ezra Pound aponta que uma grande obra pode ser revisitada sem sofrer um esgotamento, entende-se que existem, a cada fruição, novas contribuições a essa conversação assíncrona que podem surgir tanto da parte do autor como do receptor. Assim, para o pensador, uma das formas de avaliar a literatura, ou pelo menos uma das consequências da boa literatura, seria sua duração e seu impacto ou influência no leitor. Ela se torna duradoura e cria uma memória especial relacionada à vivência que o receptor teve com a obra. Torna-se uma experiência singular, como nos diz John Dewey (2010). Uma vez que nossos sentidos não podem ser simplesmente desligados, somos expostos continuamente, ininterruptamente, aos mais diversos estímulos. A esmagadora maioria destas relações com o meio, entretanto, é de tal forma corriqueira que sequer tomamos consciência delas. Mas, eventualmente, acontece: alguma peculiaridade faz com que o percurso entre provocação e percepção se torne completo, o estímulo "torna-se um todo e carrega em si seu caráter individualizador e sua autossuficiência", ou seja, aquilo "torna-se uma experiência, digna de ser assim chamada" (Dewey, 2010, p. 110). Se foi um evento de grande importância, como ser agraciado com um prêmio, ou impactante emocionalmente como uma briga, o fato é que, em maior ou menor grau, esses momentos criam uma marcação específica no curso geral da experiência do indivíduo. Agora, talvez a característica mais importante de qualquer experiência que possamos vivenciar seja exatamente o detalhe de que apenas nós, em nossa individualidade, podemos conhecê-la. De fato, nada é mais pessoal e intransferível do que a experiência pessoal com o mundo, que nos chega através das entradas biologicamente implantadas em nossos corpos: os sentidos. Podemos e usamos as diferentes linguagens para tentar descrever o que sentimos e pensamos uns aos outros, mas a experiência em si é única para cada um.

Se a literatura pode marcar-nos a vida, tornando-se uma experiência, e estas são intrinsecamente pessoais, quem poderia avaliar ou definir a qualidade de uma obra, quem poderia absorver o significado carregado no texto, a não ser o receptor? Certamente a vasta literatura mundial foi elegendo seus favoritos com base em critérios às vezes técnicos, às vezes sociais ou mesmo políticos. Existem aquelas obras que se tornam referência por tratarem deste ou daquele assunto, mas também existem aquelas que poderiam ser consideradas triviais e, ainda assim, chegam a uma penetração vultosa no gosto do público geral.

As razões para o fenômeno são diversas, mas não são o assunto deste texto. $O$ que por hora precisamos tirar destes fatos é a certeza de que toda a linguagem escrita que de alguma forma teve grande 
aceitação ou se tornou um clássico, e que vieram a ser representativas da própria identidade artística humana, são obras literárias e, portanto, são, em maior ou menor grau, carregadas de significado. O manual de instruções da sua TV sequer surge cogitado para figurar numa lista dessa natureza. A literatura, a palavra escrita enquanto arte, enquanto expressão da subjetividade humana tem um poder transformador sobre esse mesmo homem, oferecendo a cada receptor uma experiência pessoal única.

É exatamente esta percepção que nos leva ao título deste artigo. Em se tratando da literatura, portanto, o que estamos tentando traduzir? Se paramos na fisicalidade do texto, estabelecendo um comparativo palavra por palavra ou frase a frase, parece perfeitamente possível buscar os signos correspondentes de uma língua para outra. A história da tradução geral mostra que mesmo as mais complexas diferenças culturais podem ser aos poucos vencidas. Tomando uma expressão como "o menino subiu na árvore", ainda que entre dois idiomas não existam vocábulos de correspondência exata, ainda assim, dentro de duas culturas humanas certamente haverá os conceitos de menino (homem jovem), de subir (ir acima) ou de árvore (espécime vegetal).

Mas, se esse componente que faz a literatura está além do texto enquanto código-registro, encontrar uma correspondência de vocábulos ou conceitos seria o suficiente para que a obra traduzida tenha a mesma capacidade de fazer emergir o diferencial percebido no dito original? Pois se este aspecto não puder ser reproduzido no texto-alvo, dificilmente poderíamos considerar que a tradução foi um sucesso. O que existe no texto literário que buscamos traduzir?

No artigo Da Tradução como Criação e como Crítica, Haroldo de Campos discute as ideias do alemão Max Bense quanto aos diferentes tipos de informação contidas no texto literário. De acordo com o teórico, seriam três: documentária, semântica e estética. A primeira, a documentária, se encontra na esfera do mero factual, ou seja, documenta algo observável, seria uma sentença-registro. Tomando como exemplo a sentença "fulano é um homem grande", as ideias de homem - indivíduo da espécie humana - e grande - de tamanho avantajado - surgem para dar o sentido a frase e caracterizar o sujeito "fulano" através da concatenação dos conceitos: um indivíduo da espécie humana + tamanho avantajado. Quando buscamos o segundo grau de informação sugerido por Bense, a informação semântica, temos que ir além do sentido isolado das ideias de homem e grande. Existe, portanto algo a ser absorvido desta sentença que está numa dimensão além do sintagma, que pode ser manipulado ou precisa ser inferido a partir de uma interpretação do contexto, e uma forma de demonstrar isso seria simplesmente invertendo a ordem dos termos. Assim, se em vez de um homem grande, escrevermos um grande homem, imediatamente torna-se visível uma relação totalmente nova entre eles.

Na língua portuguesa, ao dizermos um homem grande, a imagem que surgiria imediatamente seria um indivíduo de grande estatura ou possivelmente gordo. Mas a inversão um grande homem em nosso idioma sugere uma relação de valoração das qualidades pessoais ou morais desse indivíduo. De fato, os escritores em língua portuguesa frequentemente brincam com a variação de efeitos semânticos que a simples reposição do adjetivo permite, pois "antes do substantivo ele assume muitas vezes um sentido figurado ou confere um matiz poético" (RONÁl, 1987, p. 22). Os conceitos presentes são os mesmos. A mera mudança de ordem gera novos sentidos semânticos, o que, para o tradutor, é de vital importância pois esta dimensão já é fortemente ligada aos aspectos gramaticais e culturais do idioma e do ambiente social. Se buscarmos apenas correlacionar os vocábulos correspondentes nesta frase na língua inglesa, por exemplo, não podemos assumir o mesmo efeito. Aliás, a formulação a man big, a princípio, seria considerada incorreta, pois a gramática deste idioma estabelece a posição do adjetivo antecedendo o substantivo como regra, o que não acontece no português. A expressão gramaticalmente correta, ou seja, a big man, até poderia se utilizar do restante do texto para transmitir uma ou outra ideia, mas se o tradutor concluiu que um grande homem se refere de fato às qualidades morais do indivíduo, provavelmente seria uma boa ideia buscar 
alternativas. Uma possibilidade seria o adjetivo great, na formulação a great man.

Para um manual técnico a simples equivalência de sentido entre os vocábulos se mostra suficiente, pois como obra fechada, seu significado não exige a contribuição do receptor. A compreensão de uma série de ações ordenadas, numa perspectiva descritiva, que permita ao leitor refazer os passos enumerados de forma objetiva é o que visa o texto técnico, como uma receita de bolo, sendo, portanto, essencialmente denotativo. Porém mais uma vez fica patente as especificidades da tradução literária, pois os objetivos do autor são subjetivos, denotação e conotação vêm e vão sem aviso ou sem esclarecimento e ainda, lembrando Pound, em diferentes gradações que podem ou não serem captadas pelo leitor/tradutor a cada fruição, visto que sua percepção do texto é uma apreensão pessoal e única.

Daí a extrema importância, para o tradutor, do conhecimento aprofundado não apenas do idioma originário, para que se possa captar as nuances mais tênues, como também do perfeito manejo do idioma alvo, para que se possa encontrar maneiras de recriar os aspectos subjetivos. Sem essa dimensão, a obra traduzida estaria certamente incompleta. Se o tradutor acalenta qualquer esperança de ser bem-sucedido na transmissão de conteúdo do texto entre idiomas, jamais poderia descuidar-se disto. Por isso retorna a pergunta: em tradução literária, o que estamos tentando traduzir? Se a obra literária não se confina aos limites do que está escrito, é preciso traduzir mais do que as palavras ali dispostas. Roman Jakobson (2007) sugere que:

\begin{abstract}
ao traduzir de uma língua para outra, substituem-se mensagens em uma das línguas, não por unidades de código separadas, mas por mensagens inteiras de outra língua. Tal tradução é uma forma de discurso indireto: o tradutor recodifica $\mathrm{e}$ transmite uma mensagem recebida de outra fonte. Assim, a tradução envolve duas mensagens equivalentes em dois códigos diferentes (JAKOBSON, 1976, p. 65).
\end{abstract}

Ou seja, diante da obra literária, para garantir na tradução a fidelidade à obra, a metáfrase não é suficiente, pois a correspondência de sentido dos vocábulos nem sempre é igual a correspondência semântica das frases: o tradutor precisa ser infiel ao texto escrito. Neste momento, a questão ética explode na mente de qualquer um que reflita sobre a atividade tradutória. Os tradutores percebem que tem nas mãos um poder não apenas criador, mas manipulador e possivelmente destruidor. A verdade é que todo profissional da área já precisou debater-se com a "tentação diabólica de fazermos a tradução superior ao original" (SILVEIRA apud RONÁl, 1987, p. 39). A equivalência é a meta a ser alcançada. Mas sempre é bom lembrar que estamos discutindo expressões da subjetividade humana, e por isso o que the seria equivalente também está sujeito à subjetividade. Não por acaso tornou-se emblemático o movimento francês de tradutores conhecido como Les Belles Infidèles, que perdurou entre os séculos XVII e XVIII, onde a ideia de equivalência entre original e tradução tinha aspectos bem diferentes do que se entende hoje em dia.

Por direcionar-se exatamente ao texto literário, os tradutores franceses da época tinham como aspecto mais importante da relação leitor-obra a experiência emocional proporcionada. Ou seja, "a tradução tinha de proporcionar ao leitor a impressão semelhante à que o original teria suscitado" (MILTON, 1998, p. 57). Com esse objetivo, não apenas deixavam em segundo plano a fidelidade ao escrito, como alguns deles não tinham qualquer pudor em fazer cortes ou mesmo acréscimos que julgassem necessários para garantir essa "impressão" semelhante. Considera-se que a atividade tradutória sempre parte, em princípio, de duas macro possiblidades em se tratando da condução do trabalho: a primeira seria manter o foco no texto, na preocupação com a equivalência textual, buscando uma tradução palavra por palavra ou metáfrase, que já demonstramos ser insuficiente e mesmo inadequada para o texto literário; a segunda seria inverter o foco para o leitor, buscando trabalhar a partir da experiência que o texto traduzido deve proporcionar, utilizando de paráfrases ou substituições para garantir uma leitura fluida e afeita ao leitor, minimizando os efeitos da mudança de contexto sociocultural. De certa forma, o movimento francês ia ao oposto extremo da metáfrase, ultrapassando mesmo a paráfrase.

Após este pequeno desvio, que logo ficará mais claro, podemos retornar a Max Bense e à terceira 
categoria de informação sugerida pelo teórico, a estética. De acordo com o alemão, esta transcende as duas primeiras pela ligação intrínseca com a própria forma e ordenação dos signos. No caso da informação semântica, como exemplificado, esta pode demonstrar fragilidade diante da reposição ou escolha dos vocábulos utilizados, mas ainda é passível de ser codificada em mais de uma forma. Já para informação estética esta fragilidade, segundo Bense, atinge seu grau máximo, não permitindo qualquer variação sem que, com isso, ela se perca. Certamente isso se torna mais perceptível na escrita poética, onde a forma ganha importância na apresentação da obra, mas muitos textos em prosa também podem estar carregados desta dimensão de significado.

Com minha brandura, alegre é que eu matava. Mas, as barbaridades que esse delegado fez e aconteceu, o senhor nem tem calo em coração para poder me escutar. Conseguiu de muito homem e mulher chorar sangue, por este simples universozinho aqui. Sertão. $O$ senhor sabe: sertão é onde manda quem é forte, com as astúcias. Deus mesmo, quando vier, que venha armado!

O trecho acima é parte do romance Grande Sertão: Veredas, de Guimarães Rosa. É muito claro que o autor não buscou, prioritariamente, a clareza da informação documental, pois as frases utilizam ordenação bastante peculiar de palavras e mesmo de ideias. Também se poderia certamente sugerir formas de reescrever o texto de modo a facilitar a absorção do contexto semântico, mas assim se perderia exatamente "o tratamento da palavra como objeto" (CAMPOS, 2019: 4). Por isso Max Bense define a informação estética como dotada de fragilidade máxima. "O total de informação de uma informação estética é em cada caso igual à sua realização" (BENSE, 1958 apud CAMPOS, 2019, p. 5), o que implicaria em sua definitiva intraduzibilidade, pois, em outra língua, seria nova informação estética, distinta da primeira, ainda que possa ser comparável a nível semântico ou documentário.

\section{Considerações Finais}

Diante dos temas discutidos, poder-se-ia afirmar que um leitor só pode conhecer de fato as obras de Vitor Hugo se compreender o francês em que foi escrito. Da mesma forma, quem não possui o conhecimento do português estaria impossibilitado de ter a experiência de Guimarães Rosa, pois tanto um como o outro seriam intraduzíveis em sua completude.

Ora, a atividade tradutória existe. Ninguém questiona esse fato. Se encontra dificuldades únicas diante do trabalho sobre o texto literário, ainda assim realiza sua tarefa. Talvez seja correto afirmar, como sugerido acima, que só seja possível experienciar integralmente uma obra em seu idioma de origem, mas há algo que se pode levar do original à tradução. Completude, portanto, é a palavra que precisa ser sublinhada. É onde surge o trabalho do tradutor enquanto criador ele mesmo. Afinal, tenhamos dois ou mais tradutores no exercício em cima de um mesmo texto, de tamanho razoável, a possiblidade de chegarmos a duas obras iguais seria tão reduzida que até podemos considerá-la na casa das nulidades. Isso é uma verdade mesmo para um texto técnico, que dirá para as dimensões subjetivas da obra literária.

Não por acaso Haroldo de Campos faz notar que a palavra tradução sequer parece ser a mais apropriada, suas reflexões acerca do problema passam até mesmo por "reelaboração neológica", com a cunhagem de termos como transcriação, reimaginação ou transtextualização dentre outros: "essa cadeia de neologismos exprimia, desde logo, uma insatisfação com a ideia "naturalizada" de tradução, ligada aos pressupostos ideológicos de restituição da verdade e literalidade" (CAMPOS, 2019, p. 79).

O senso comum supõe que toda tradução é um processo fiel e indiscutível de transposição de um conteúdo de uma língua para outra, mas isso não apenas se mostra impossível como também torna impossível, salvo casos em que a mudança ou é deliberada ou fruto de pouca competência técnica, determinar, dentre duas obras traduzidas, qual seria a melhor ou mais correta. É importante lembrar que o tradutor também é, em primeira instância, um receptor da obra. Sendo assim, também faz parte da cooperação que se cria entre autor e leitor, também guardará consigo sua própria experiência com a obra e, forçosamente, fará sua contribuição para a cúmplice conversação que se forma. Em outras palavras, o 
tradutor, a princípio, é refém de sua própria vivência com a obra e é só a partir desta ele pode produzir o texto-alvo. Dessa forma, se a tradução ideal é uma ilusão, ainda assim a obra traduzida ganha sua própria completude, pois o tradutor toma de sua própria subjetividade para repor na obra aquilo que está além da fisicalidade do texto.

Talvez por isso há quem diga que somente bons poetas poderiam traduzir poesia, ou que a prosa literária exige em sua tradução a mão de um bom escritor. Certamente se pode compreender posicionamento. Porém isso ainda nos parece uma necessidade de atrelar à práxis da tradução a uma disciplina que Ihe seria superior. Em vez disso, o mais acertado seria entender que a tradução literária já percebeu a necessidade de reconstruir seu passado e encontrar sua própria história. Já encontrou suas problemáticas específicas, seus próprios paradigmas, e, portanto, já pode pensar seu lugar como disciplina própria.

\section{REFERÊNCIAS}

CAMPOS, Haroldo de. A arte no horizonte do provável. 5. ed. São Paulo: Perspectiva, 2019.

CAMPOS, Haroldo de. Transcriação. 1. ed. São Paulo: Perspectiva, 2019.

DEWEY, John. Arte como experiência. 1. ed. São Paulo: Martins Fontes, 2016.

ECO, Umberto. Obra Aberta. 8. ed. São Paulo: Perspectiva, 1991.

GRICE, H. Paul. Logic and Conversation. In: Speech Acts. p. 41-58. University of California. Disponível em: <https://doi.org/10.1163/9789004368811_003>.

Acesso em: 20 de abr. 2021.

JAKOBSON, Roman. Linguística e Comunicação. 24. ed. São Paulo: Cultrix, 2007.

MILTON, John. Tradução: Teoria e Prática. 2. ed. São Paulo: Martins Fontes, 1998.

PAZ, Octavio. Tradução: Literatura e Literalidade. Fale/UFMG, 2009. Disponível em: <http://www.letras.ufmg.br/padrao_cms/documentos/e ventos/vivavoz/traducao2ed-site.pdf>. Acesso em: 20 de abr. 2021.

POUND, Ezra. ABC da Literatura. 11. ed. São Paulo: Cultrix, 2006.

RÓNAI, Paulo. Escola de Tradutores. 6. ed. Rio de Janeiro: Nova Fronteira, 1987.

\section{COMO CITAR ESSE ARTIGO}

DA SILVA, Marco David Castro. Tradução Literária: O que tentamos traduzir?. Signo, Santa Cruz do Sul, v. 46, n. 87, sep. 2021. ISSN 1982-2014. Disponível em: <https://online.unisc.br/seer/index.php/signo/article/view/1 6523>. doi:https://doi.org/10.17058/signo.v46i87.16523. 